\title{
Adult-Type Rhabdomyoma of Larynx: A Rare Cause of Difficult Tracheal Intubation
}

\section{Erişkin Tipte Laringeal Rabdomiyom: Zor Trakeal Entübasyonun Nadir Bir Nedeni}

\author{
Barış ERDOĞAN, ${ }^{1}$ Mehmet Özgür ERDOĞAN, ${ }^{2}$ Zeynep Aslı BATUR ÇALIŞ' \\ ${ }^{1}$ Department of Otolaryngology, Şişli Etfal Training and Research Hospital, İstanbul; \\ ${ }^{2}$ Department of Emergency Medicine, Haydarpaşa Numune Training and Research Hospital, İstanbul
}

\begin{abstract}
SUMMARY
Adult-type rhabdomyoma is a rare benign mesenchymal tumor seen in adults that becomes symptomatic after a long period of slow growth. It almost always originates from tissues of the head and neck containing striated muscle. The symptoms of rhabdomyoma include dysphagia, hoarseness, and globus. This report presents the case of a 60-year-old woman with isolated adult-type rhabdomyoma of the piriform sinus who presented with dyspnea and difficult tracheal intubation. The report emphasizes the importance of evaluating patients with upper airway obstruction for laryngeal masses before intubation.
\end{abstract}

Key words: Intubation; larynx; rhabdomyoma.

\section{ÖZET}

Erişkin tipte laringeal rabdomiyom yetişkinlerde görülen, yavaş büyümesine bağlı uzun sürede semptomatik olan, benign mezenkimal bir tümördür. Genellikle, baş ve boyun düz kaslarından kaynaklanır. Rabdomiyomlar disfaji, ses kısıklığı ve boğazda cisim hissine neden olurlar. Bu yazıda, üst hava yolu tıkanıklıklarında entübasyon öncesi laringeal kitle açııından değerlendirmenin önemini, dispne ve zor trakeal entübasyona neden olan piriform sinüs kaynaklı erişkin tipte laringeal rabdomiyom olgusu üzerinden anlatmaktadır.

Anahtar sözcükler: Entübasyon; larinks; rabdomiyom.

\section{Introduction}

Rhabdomyomas are benign, slow-growing tumors that arise from striated muscle. Since they grow slowly, it takes a long time for rhabdomyomas to become symptomatic. Rhabdomyomas are classified as either cardiac or extracardiac. ${ }^{[1,2]}$ Cardiac rhabdomyomas are usually part of a congenital disorder, such as tuberous sclerosis. Adult-type rhabdomyomas are almost always solitary lesions found in the head and neck. Most cases present with dysphagia, difficulty breathing, and globus. In rare situations, when complicated by a more common upper airway problem, such as allergies or laryngeal spasm, laryngeal rhabdomyomas may cause life-threatening obstructions and lead to difficult tracheal intubation. Here, we present the first reported laryngeal rhabdomyoma exacerbating dyspnea in synergy with drug-induced laryngeal angioedema.

\section{Case Report}

A 60-year-old female was transferred from the Radiology Department to the Emergency Department with dyspnea after receiving contrast medium during magnetic resonance imaging (MRI) of the neck to evaluate recurrent hoarseness. She was believed to have a severe upper airway obstruction and laryngeal edema due to hypersensitivity to the contrast agent. She had a history of hypothyroidism. Arterial blood gas analysis showed the following: $\mathrm{PaCO}_{2} 30 \mathrm{mmHg}, \mathrm{PaO}_{2}$ $52 \mathrm{mmHg}$, and $\mathrm{SaO}_{2} 87 \%$. Her blood count and biochemistry were normal. She was given $60 \mathrm{mg}$ of methylprednisolone, $0.25 \mathrm{mg}$ of adrenaline, and $45 \mathrm{mg}$ of pheniramine intravenously. However, her blood oxygen saturation did not increase after the administration of these drugs. Thus, tracheal intubation was deemed necessary.

Submitted (Geliş tarihi): 12.02.2012 Accepted (Kabul tarihi): 25.04.2012 Published online (Online baskı): 07.02.2013 
After administering a muscle relaxant, laryngoscopy showed a large mass obstructing the entire airway. The patient could not be intubated using rapid sequence intubation (RSI) and required an emergency tracheostomy. An otolaryngologist was consulted regarding the mass in the larynx. Inspection of the larynx with a 70-degree telescope showed a mass originating from the left piriform sinus, filling the space between the epiglottis and the posterior wall of the larynx, and displacing the right aryepiglottic fold laterally (Figure 1a). There was hyperemia of the surrounding mucosa.

MRI performed before emergency admission showed a mass with clear borders, measuring $40 \times 20 \times 25 \mathrm{~mm}$, starting from the visceral area at the level of the hyoid bone and obliterating the aerodigestive passage completely (Figure $1 b)$. It extended caudally to the left paramedian post-cricoid zone up to the esophageal verge, and through to the left laryngeal and pharyngeal walls. The mass originated from the piriform sinus.

After an emergency tracheostomy, the patient stabilized rapidly and was admitted to the Otolaryngology Department, where the mass was excised completely via a transoral route. Microscopic examination of the tumor revealed that it was an adult-type rhabdomyoma, a rare benign mesenchymal tumor of the upper aerodigestive tract.

The patient had postoperative bleeding and had to be returned to the operating room. There were no further problems after, and she was discharged from the hospital after the tracheostomy was closed. At follow-up laryngoscopy six months post-operation, no tissue damage or recurrence was seen.

\section{Discussion}

Laryngeal rhabdomyomas are rare tumors, with about 40 reported cases. ${ }^{[3]}$ Patients with rhabdomyomas in the head and neck region usually present with hoarseness, difficulty swallowing, or snoring. Sometimes, they present with asymmetric hypertrophy of the tonsils or with a mass on the floor of the mouth. ${ }^{[4,5]}$ To our knowledge, our case is the first reported laryngeal rhabdomyoma exacerbating dyspnea in synergy with drug-induced laryngeal angioedema.

The diagnosis of rhabdomyoma is usually made late because they grow slowly and are not usually included in the differential diagnosis of a neck mass due to their rarity. ${ }^{[1,2]} \mathrm{A}$ recent review reported a male predilection of 3.3:1..$^{[6]}$ In our case, a mass covered with normal mucosa originated from the piriform sinus, totally obliterating the space between the posterior wall of the larynx and the epiglottis, and displacing the right aryepiglottic fold laterally. Rhabdomyoma was not diagnosed until intubation was attempted.
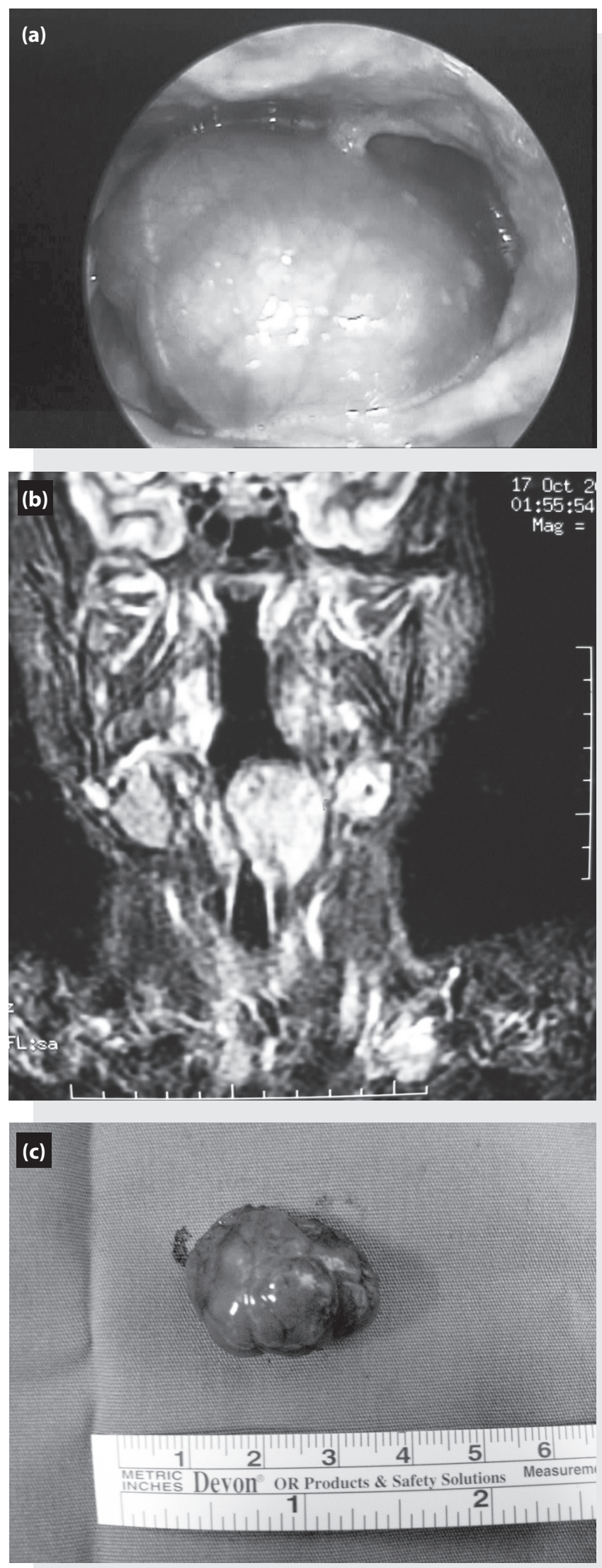

Figure 1. (a) Laryngoscopic image of mass lesion. (b) MRI of laryngeal mass lesion. (c) Mass lesion after surgical excision. 
Imaging of the upper airway obstruction in such cases is another challenge. MRI appeared to be a suitable choice for the laryngeal mass in our case, as there was initially no emergency. After the contrast medium caused angioedema, MRI was definitely not a suitable diagnostic tool. Although flair images can show the edema, these images take time to acquire. The emergent nature of the laryngeal angioedema is a major issue.

Such mass lesions are a challenge for endotracheal intubation. The emergency physician has to be aware of the management options for these laryngeal lesions. Intubation attempts may complicate upper airway obstruction because of the risk of bleeding from the mass lesions. Early examination of the larynx with laryngeal mirrors or 70-degree angled telescopes before inducing anesthesia may reduce the risk of complications when similar lesions are encountered. Recent studies suggest that ultrasound (US) evaluation of the anterior neck soft tissues may help predict difficult laryngoscopy ${ }^{[7]}$ US may be useful for diagnosing mass lesions of the larynx. Anesthetics without a muscle relaxant are not safe for RSI. ${ }^{[8]} \mathrm{RSI}$ failure carries a risk of mortality in the management of upper airway obstruction. To manage upper airway obstruction in our Emergency Department, we perform indirect laryngoscopy before RSI.

\section{Conclusions}

Emergency physicians should consider the possibility of a laryngeal mass in patients with a history of globus, dysphagia, and dyspnea. Intubation attempts may complicate upper airway obstruction because of the risk of bleeding from the mass lesions. The emergency physician should be familiar with the management of laryngeal masses.

\section{Conflict of Interest}

The authors declare that there is no potential conflicts of interest.

\section{References}

1. Delides A, Petrides N, Banis K. Multifocal adult rhabdomyoma of the head and neck: a case report and literature review. Eur Arch Otorhinolaryngol 2005;262:504-6.

2. Koutsimpelas D, Weber A, Lippert BM, Mann WJ. Multifocal adult rhabdomyoma of the head and neck: a case report and literature review. Auris Nasus Larynx 2008;35:313-7.

3. Farboud A, Pratap R, Helquist H, Montgomery P. An unusual cause of obstructive sleep apnoea. J Laryngol Otol 2009;123:22.

4. Karaman E, Saritzali G, Ozcora E. Rhabdomyoma of the tonsillar fossa. J Craniofac Surg 2009;20:1207-9.

5. Bellis D, Torre V, Nunziata R, Demarchi A, Fornaseri V, Coverlizza S, et al. Submandibular rhabdomyoma: a case report. Acta Cytol 2006;50:557-9.

6. Papaspyrou G, Werner JA, Roessler M, Devaney KO, Rinaldo A, Ferlito A. Adult rhabdomyoma in the parapharyngeal space: report of 2 cases and review of the literature. Am J Otolaryngol 2011;32:240-6.

7. Kundra P, Mishra SK, Ramesh A. Ultrasound of the airway. Indian J Anaesth 2011;55:456-62.

8. Akköse Ş, Armağan E, Bulut M, Çebiççi H. Hızlı Entübasyon Protokolünde Etomidat Tek Başına Yeterli mi? Tr J Emerg Med 2001;1:1-5. 